\title{
Cloud-to-Ground Lightning Response to Aerosol over Air-Polluted Urban Areas in China
}

\author{
Haichao Wang ${ }^{1}$, Zheng Shi ${ }^{1,2, *}$, Xuejuan Wang ${ }^{1}$, Yongbo Tan ${ }^{1}$, Honglei Wang ${ }^{1}$, Luying Li ${ }^{1}$ and Xiaotong Lin ${ }^{1}$ \\ 1 Key Laboratory of Meteorological Disaster, Ministry of Education (KLME)/Joint International Research \\ Laboratory of Climate and Environment Change (ILCEC)/Collaborative Innovation Center on Forecast and \\ Evaluation of Meteorological Disasters (CIC-FEMD)/Key Laboratory for Aerosol Cloud-Precipitation of \\ China Meteorological Administration, Nanjing University of Information Science \& Technology, \\ Nanjing 210044, China; 20181206008@nuist.edu.cn (H.W.); wxj@nuist.edu.cn (X.W.); ybtan@ustc.edu (Y.T.); \\ 002742@nuist.edu.cn (H.W.); 20181206005@nuist.edu.cn (L.L.); 20191206005@nuist.edu.cn (X.L.) \\ 2 State Key Laboratory of Severe Weather, Chinese Academy of Meteorological Sciences, Beijing 100081, China \\ * Correspondence: 002744@nuist.edu.cn
}

check for updates

Citation: Wang, H.; Shi, Z.; Wang, X.; Tan, Y.; Wang, H.; Li, L.; Lin, X. Cloud-to-Ground Lightning Response to Aerosol over Air-Polluted Urban Areas in China. Remote Sens. 2021, 13, 2600. https:// doi.org/10.3390/rs13132600

Academic Editor: Carmine Serio

Received: 16 May 2021

Accepted: 30 June 2021

Published: 2 July 2021

Publisher's Note: MDPI stays neutral with regard to jurisdictional claims in published maps and institutional affiliations.

Copyright: (c) 2021 by the authors. Licensee MDPI, Basel, Switzerland. This article is an open access article distributed under the terms and conditions of the Creative Commons Attribution (CC BY) license (https:/ / creativecommons.org/licenses/by/ $4.0 /)$.

\begin{abstract}
The effect of aerosols on lightning has been noted in many studies, but much less is known about the long-term impacts in air-polluted urban areas of China. In this paper, 9-year data sets of cloud-to-ground (CG) lightning, aerosol optical depth (AOD), convective available potential energy (CAPE), and surface relative humidity (SRH) from ground-based observation and model reanalysis are analyzed over three air-polluted urban areas of China. Decreasing trends are found in the interannual variations of CG lightning density (unit: flashes $\mathrm{km}^{-2} \mathrm{day}^{-1}$ ) and total AOD over the three study regions during the study period. An apparent enhancement in CG lightning density is found under conditions with high AOD on the seasonal cycles over the three study regions. The joint effects of total AOD and thermodynamic factors (CAPE and SRH) on CG lightning density and the percentage of positive CG flashes (+CG flashes/total CG flashes $\times 100$; PPCG; unit: \%) are further analyzed. Results show that CG lighting density is higher under conditions with high total AOD, while PPCG is lower under conditions with low total AOD. CG lightning density is more sensitive to CAPE under conditions with high total AOD.
\end{abstract}

Keywords: aerosol; cloud-to-ground lightning; urban

\section{Introduction}

Lightning is one of the deadliest meteorological phenomena and causes severe damage to infrastructure or causes forest fires [1-3]. Cloud-to-ground (CG) lightning, accounting for about $25 \%$ of total lightning (including CG lightning and intracloud lightning), is one of the major causes of nature-related fatalities throughout the world. During 1997-2009, CG lightning caused 5022 deaths and 4670 injuries in China [4]. Therefore, it is important to study and understand the activity of CG lightning to protect and mitigate against the harmful impacts of it.

Since Westcott [5] first linked lightning enhancement with urban aerosols, many studies have demonstrated the aerosol effects on lightning activity. Altaratz et al. [6] investigated the relationship between lightning and smoke in the Amazon and found that increasing aerosol loading leads to deeper clouds with more intense lightning. Yuan et al. [7] reported a more than $150 \%$ increase in lightning flashes over the West Pacific Ocean due to a $\sim 60 \%$ increase in aerosol loading produced by volcanic activity. Thornton et al. [8] showed a significant enhancement of lightning density over shipping lanes in the northeastern Indian Ocean and the South China Sea, which is related to the aerosols emitted by maritime vessels. Some studies showed a link between CG flashes and smoke from forest fires [9-11]. Numerous works found an enhancement of CG lightning caused by urban aerosols [12-17]. Therefore, a host of researches have been conducted to present the influence of aerosol on electrification in thunderstorms. 
In general, the aerosol effects include both microphysical and radiative effects [18]. By acting as cloud condensation nuclei (CCN), increasing aerosol loading reduces the mean size of cloud droplets and increases its number concentration with fixed liquid water content [19]. The small size of cloud droplets suppresses coalescence, delays the onset of warm-rain processes, and extends the lifetime of clouds [20,21]. This allows more liquid water to enter above the $0{ }^{\circ} \mathrm{C}$ level of the atmosphere, increasing the content of supercooled water in a thunderstorm $[22,23]$ and enhancing the ice-phase process. Meanwhile, charge separation between rebounding collisions ice particles (graupel and ice crystal) in the presence of super-cooled water is referred to as the primary electrification process in thunderstorms [24-26]. Therefore, the microphysical effects of aerosol have a vital influence on lightning activity. On the other hand, aerosols can reduce the solar radiation reaching the surface through absorbing, reflecting, and scattering solar radiation, heat the atmospheric layer, cool the surface, and thus stabilize the atmosphere [27-30]. This leads to less convection and electrical activity production.

Lightning and aerosol loading are also affected by the local meteorological conditions [31]. It is very challenging to disentangle the impacts of thermodynamics and aerosols on cloud properties and lightning production [32]. The strengths of lightning and convection are controlled by various thermodynamic factors such as convective available potential energy (CAPE) [33-35] and relative humidity in the lower and middle troposphere [36-38]. These factors will dictate the instability of the atmosphere and thus will influence the updrafts, cloud base height, and cloud depth. In addition, the effects of aerosols on lightning activity and convection are also related to aerosol type. Absorbing aerosols exert more influence on aerosol radiative effects and tend to suppress thunderstorms, while hygroscopic aerosols tend to invigorate thunderstorms under suitable meteorological conditions due to aerosol microphysical effects [18,39]. Wang et al. [40] investigated the long-term effect of aerosol on lightning over Africa. They found the lightning and convection may gradually be suppressed as aerosol optical depth (AOD) increased over northern Africa, where it is drier and dominated by dust aerosols, while this suppressed effect of aerosol is insignificant over central Africa, where it is moist and dominated by smoke aerosols.

In the past decades, due to the large increase in anthropogenic emissions over urban areas, China has suffered serious air pollution over these areas. Some studies have investigated the link between polluted aerosols and intense convective activities in China. Zhao et al. [41] found the CG lightning in Sichuan is positively correlated with aerosols in the plateau region and negatively correlated with aerosols in the basin region using 13 years (2005-2017) of CG lightning-detected data and reanalysis data. Yang et al. [42] reported a decrease in the frequency of thunderstorms due to the increase in aerosol loading during 1951-2005 in Shanxi Province. An increasing trend in thunderstorms, lightning activities, and aerosol loading was observed during 1998-2012 in southeast China [43]. In Nanjing, Tan et al. [44] found that increasing aerosol concentration reduced solar radiation reaching the surface and the CAPE, inhibiting the intensity of lightning activity over Nanjing (China) during 2002-2011. In the Pearl River Delta, aerosol loading was found inversely correlated with heavy rainfall and lightning flashes from 2000 to 2006 [45]. However, the air pollution in China has been improved in recent years due to the implementation of various environmental protection measures. A significant decrease in AOD and concentration of $\mathrm{NO}_{2}$ and $\mathrm{SO}_{2}$ were observed over the main polluted urban regions. [46]. In this present study, we select three typically air-polluted regions with large cities in China and investigate the long-term relationships between the CG lightning and aerosols over these regions during 2010-2018. CAPE and surface relative humidity (SRH) are selected to represent the local thermodynamic conditions, and their effects on aerosol and CG lightning are also discussed. Section 2 describes the data sets and methodology used in the study. The regions of interest are also shown in this section. Section 3 presents the temporal features of CG lightning and aerosols, the joint effects of aerosol, CAPE, and SRH on CG lightning. The discussions of key findings in this study are given in Section 4. 


\section{Data and Methods}

\subsection{Data Collections}

The data of cloud-to-ground (CG) lightning, aerosol optical depth (AOD), and thermodynamic factors during 2010-2018 are used in this study. The CG lightning data were obtained from China Meteorological Administration (CMA) and China National Meteorological Center (CNMC). The CG lightning data were detected by the China Lightning Detection Network (CLDN), which is based on the ground-based Advanced Time of Arrival and Direction (ADTD) system CG lightning detection sensors. The Improved Performance through Combined Technology (IMPACT) method is used in this system, which combines the information of direction and the time-of-arrival technology to detect the location of CG lightning [47]. CLDN is formed by 357 sensors over the majority of China and covers almost all parts of central and eastern China. The detection efficiency of the CLDN is between $82 \%$ and $90 \%$. It provides information about the time, location, polarity, and peak current of the CG flashes $[48,49]$. To eliminate the possible cloud discharge contaminations, positive CG flashes less than $15 \mathrm{kA}$ are removed [50].

The AOD in $550 \mathrm{~nm}$ is used to characterize the aerosol concentration in this study. AOD data are provided by the Modern-Era Retrospective Analysis for Research and Applications, version 2 (MERRA-2), with a spatial resolution of $0.5^{\circ} \times 0.625^{\circ}$. This data set provides the AOD of total aerosol, black carbon, organic carbon, sulfate, and dust. MERRA-2 uses the GEOS-5 (Goddard Earth Observing System, version 5) Earth system model and three-dimensional variational data assimilation (3DVar) Gridpoint Statistical Interpolation analysis system (GSI) [51,52]. The GEOS-5 model is radiatively coupled to the Goddard Chemistry Aerosol Radiation and Transport model (GOCART) [53,54] aerosol module and can simulate five types of aerosols (dust, sea salt, sulfate, black carbon, and organic carbon). The aerosol and meteorological observations are jointly assimilated within GEOS-5. For aerosol data, it involved ground and satellite AOD observations, including surface-based AERONET AOD observations at $550 \mathrm{~nm}$ (1999-2014), reflectance from the Advanced Very-High-Resolution Radiometer (AVHRR) sensor (1979-2002), reflectance from the MODIS on Terra (2000-present) and Aqua (2002-present), and AOD retrievals from MISR (2000-2014). The values and spatial distributions of MERRA-2 aerosol products are in good agreement with satellite, aircraft, and ground-based observations [55]. Sun et al. [56] compared the instantaneous AOD (550 nm) between Aerosol Robotic Network (AERONET) and MERRA-2 and found a strong positive relationship between them in four seasons over China. The correlation coefficients (R) were 0.88 (spring), 0.92 (summer), 0.91 (autumn), and 0.87 (winter). A good agreement between MERRA-2 and MODIS AODS over China during 2003-2017 was also obtained by them. In this study, the total AOD $(550 \mathrm{~nm})$ from MERRA-2 was investigated. We compared monthly total AOD (550 nm) data from MERRA-2 and satellite observed AOD $(550 \mathrm{~nm})$ data from the Moderate Resolution Imaging Spectroadiometer (MODIS) aboard the Terra and Aqua satellites for four seasons over the three study regions during the study period and found a significantly positive correlation between them (as seen in Figures A1-A3).

CAPE and SRH are selected in this study to investigate the effects of thermodynamic factors in lightning activity. Monthly CAPE and SRH data are gained from the European Centre for Medium-Range Weather Forecast (ECMWF) ERA-5 reanalysis product with a spatial resolution of $0.25^{\circ} \times 0.25^{\circ}$.

\subsection{Regions of Interest}

The three study regions are shown in Figure 1, which are represented with R1 $\left(28^{\circ} \sim 32^{\circ} \mathrm{N}, 103^{\circ} \sim 107^{\circ} \mathrm{E}\right), \mathrm{R} 2\left(29^{\circ} \sim 33^{\circ} \mathrm{N}, 111^{\circ} \sim 115^{\circ} \mathrm{E}\right)$, and $\mathrm{R} 3\left(34^{\circ} \sim 38^{\circ} \mathrm{N}, 115^{\circ} \sim 119^{\circ} \mathrm{E}\right)$. The spatial distributions of 9-year (2010-2018)-total AOD and the map of terrain are also shown in Figure 2. The study regions are marked with black rectangles. All study regions contain large urban areas (such as Chengdu, Wuhan, and Jinan) and dense populations. All study regions suffer from air pollution, which is mainly caused by anthropogenic air 
pollutants. The values of total AOD over the study regions are relatively higher than that over the other regions of China (as seen in Figure 2a).

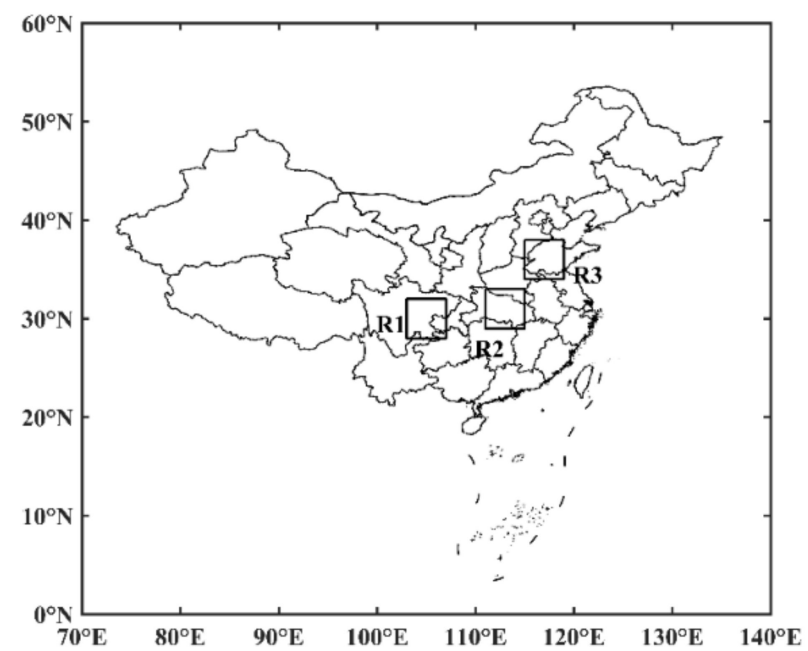

Figure 1. The regions of interest in this study (marked by black rectangles, R1: $28^{\circ} \sim 32^{\circ} \mathrm{N}, 103^{\circ} \sim 107^{\circ} \mathrm{E}$; R2: $29^{\circ} \sim 33^{\circ} \mathrm{N}, 111^{\circ} \sim 115^{\circ} \mathrm{E}$; R3: $\left.34^{\circ} \sim 38^{\circ} \mathrm{N}, 115^{\circ} \sim 119^{\circ} \mathrm{E}\right)$.

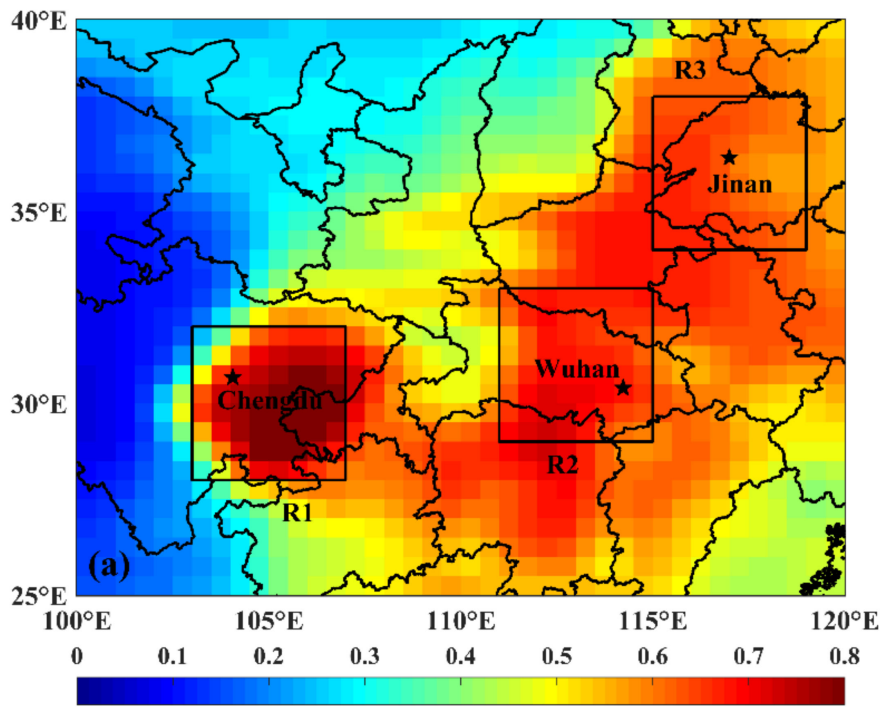

MERRA Total AOD

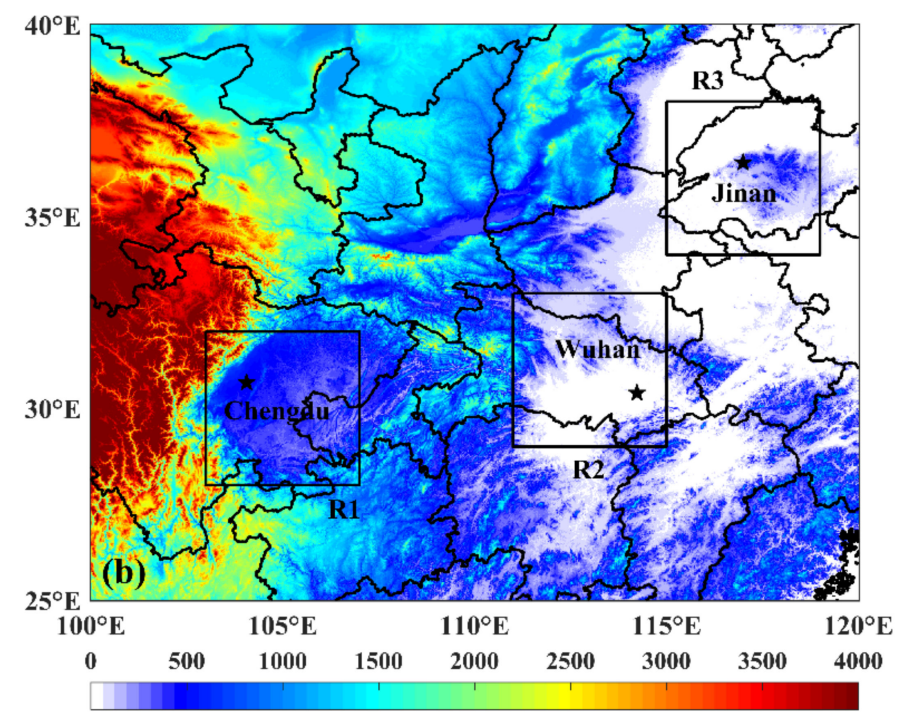

Altitude (m)

Figure 2. (a) Spatial distribution of total AOD during 2010-2018 with a spatial resolution of $0.5^{\circ} \times 0.5^{\circ}$. The regions of interest in this study are marked with black rectangles, and the major cities in each study region are marked with black asterisks. (b) The map of terrain (unit: $\mathrm{m}$ ). All AOD data are derived from the MERRA-2 data set.

\subsection{Methods}

Each study region was divided into 64 grid cells with a 0.5-degree horizontal resolution in each month. The data of total AOD, CAPE, and SRH are interpolated to a horizontal resolution of $0.5^{\circ} \times 0.5^{\circ}$. The value of CG lightning density (unit: flashes $\mathrm{km}^{-2} \mathrm{day}^{-1}$ ) and the percentage of positive CG lightning (+CG flashes/total CG flashes $\times 100$; PPCG; unit: $\%$ ) in each grid cell is calculated. The analyzed data set included the grid cells with at least one detected CG flash or the PPCG of the cell is higher than 0. In addition, the total AOD range in this study was set between 0 and 1 . A three-months-moving mean was applied in all data to smooth their seasonal fluctuation. To show the effect of aerosol on CG lightning, we compared CG lightning under clean, medium, and polluted conditions according to the value of total AOD. The data sets were first sorted by the value of total AOD from 
small to large, and the lowest or highest third of the total AOD range was labeled as clean or polluted condition, and the middle group was labeled as medium condition. The Pearson linear correlation coefficient was used in this study to measure the strength of the relationship between two factors [57]. The correlation was significant when it passed the significance test at the 0.05 level.

\section{Results}

\subsection{Temporal Variations of Total AOD and CG Lightning}

The seasonal cycles of CG lightning density (unit: flashes $\mathrm{km}^{-2} \mathrm{day}^{-1}$ ) and total AOD over the three study regions are shown in Figure 3. The CG lightning in all three study regions is active in summer and weak in winter. This seasonal variation is mainly controlled by the seasonal variations in thermodynamic conditions. The total AOD in R2 reaches a peak in spring and changes little in other seasons (Figure 3b). The value of total AOD in R1 is large in winter and small in summer. In contrast to R1, the peak total AOD in R3 occurs in summer (Figure 3b). The cold air in winter, coupled with the special topography of R1 (surrounded by mountains), is not conducive to the diffusion of aerosols [41,58], while the heavy precipitation in summer may clean the atmospheric aerosols and reduce the AOD. In R3, the humid condition in summer is conducive to the conversion of sulfur dioxide into sulfate, which may cause a high AOD in summer. Comparing the seasonal variations of CG lightning density and total AOD, no obvious correlations between them can be found in a seasonal timescale.
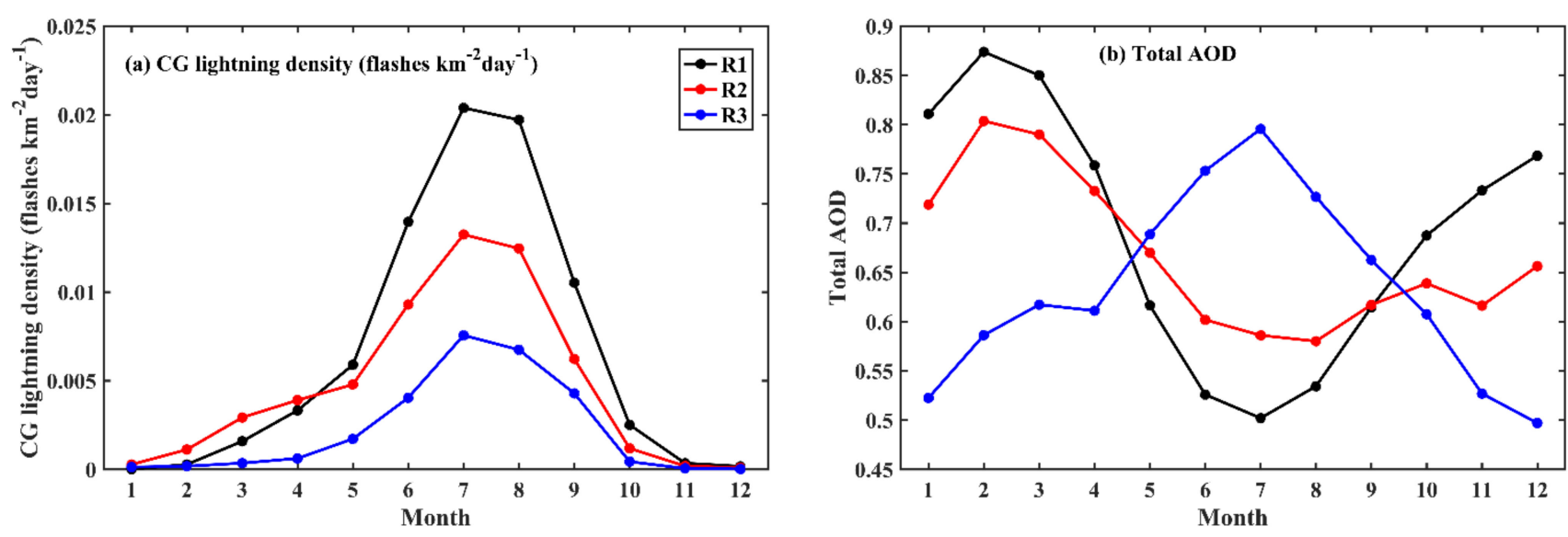

Figure 3. Monthly variations in mean (a) CG lightning density (unit: flashes $\mathrm{km}^{-2} \mathrm{day}^{-1}$ ) and (b) total AOD during 2010-2018 over three study regions R1, R2, and R3). All AOD data are derived from MERRA-2.

The interannual variations of CG lightning density and total AOD over the three study regions are shown in Figure 4. The CG lightning density displays a downward trend in all three study regions during the study period (Figure $4 \mathrm{a}$ ). The mean CG lightning density during 2014-2018 decreases 49.6\%, 44.8\%, and 61.4\% in R1, R2, and R3 compared with those during 2010-2013. Similar to CG lightning density, the interannual total AOD also shows a decreasing trend during 2010-2018 (Figure 4b) over the three study regions. Comparing the mean values of total AOD during 2014-2018 and 2010-2013, 14.9\%, 15.3\%, and $12.4 \%$ decreases are found in R1, R2, and R3. The strict measures implemented by the Chinese since 2013 reduced the anthropogenic emissions [44], and thus may cause the decreases of the AOD over the three regions. Comparing the interannual variations of CG lightning density and total AOD, a similar variation can be found between them in this timescale. 

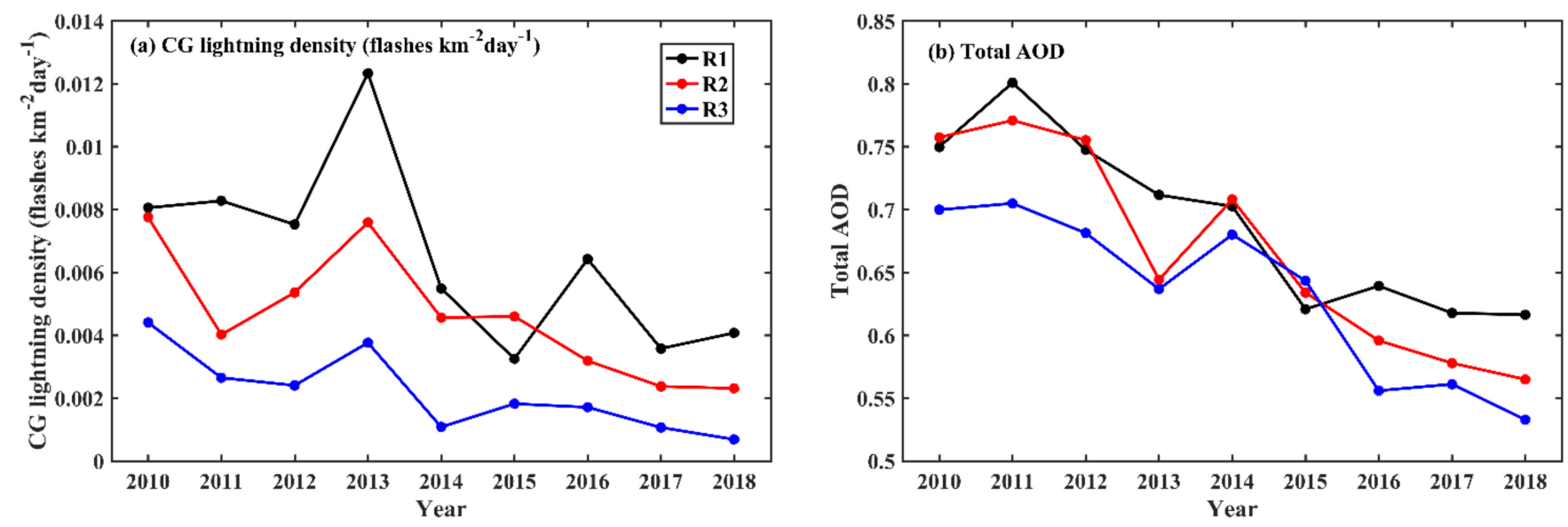

Figure 4. Interannual variations of (a) CG lightning density (unit: flashes $\mathrm{km}^{-2} \mathrm{day}^{-1}$ ) and (b) total AOD during 2010-2018 over three study regions (R1, R2, and R3). All AOD data are derived from MERRA-2.

To further analyze the relationships between CG lightning and aerosols, Figure 5 shows the box plots of CG lightning density dispersions under clean, medium, and polluted conditions in each month throughout the year over R1, R2, and R3 during the study period. The clean, medium, and polluted conditions are according to the values of total AOD. The data number of each box in each month can be found in Table A1. In R1, the CG lightning density is significantly higher under conditions with large total AOD in months with CG lightning occurrence (Figure 5a). In R2 and R3, an enhancement of the summer CG lightning density can be found under medium or polluted conditions compared with those under clean conditions but changes between medium and polluted conditions. These results suggest that the CG lightning activity may be more active under conditions with more aerosols. Aerosols can invigorate thunderstorms and lightning production by affecting the cloud microphysical processes by acting as the cloud condensation nuclei (CCN) or ice nuclei (IN). However, excessive aerosol concentration may suppress the lightning activity through aerosol radiative effects by absorbing, scattering, and reflecting the solar radiation. As the results showed R2 and R3, the changes of CG lightning density from medium conditions to polluted conditions can be decreasing or not apparent. This may be explained by the joint effects of aerosol microphysical effects and aerosol radiative effects under conditions with high aerosol concentration, which may cause the insignificant relationship between lightning activity and aerosols or even suppress the lightning activity. This nonlinear relationship between lightning activity and aerosols was reported in many studies $[6,40,59,60]$. 


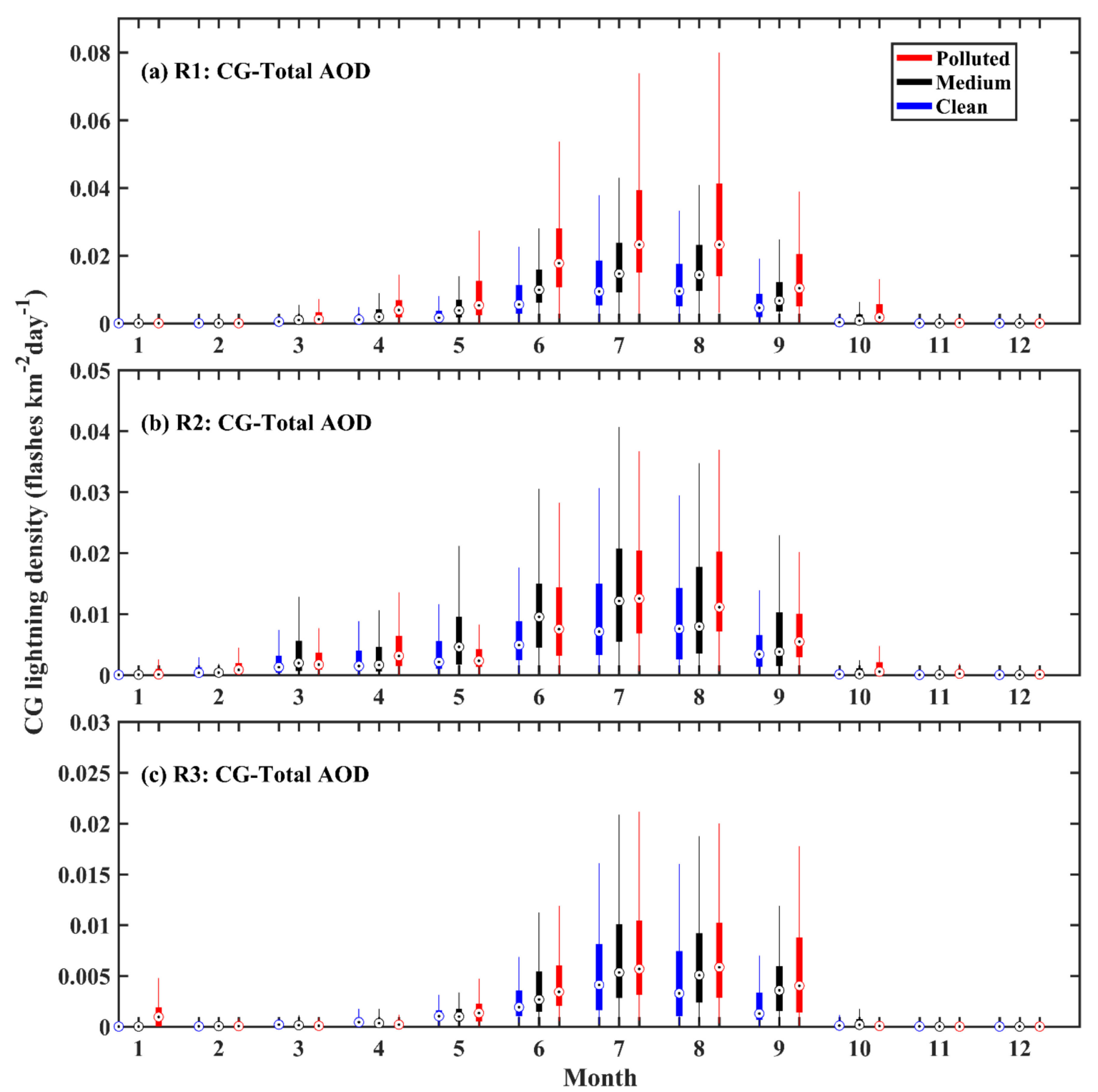

Figure 5. Box plots of CG lightning density (unit: flashes $\mathrm{km}^{-2} \mathrm{day}^{-1}$ ) dispersion showing the values of CG lightning density under relatively clean (blue), medium (black), and polluted (red) conditions in each month over (a) R1, (b) R2, and (c) R3 during 2010-2018. The distance between the bottom and the top of the box represents the 25th to 75th percentile of the data in this box. The white circle in each box represents the median. The end of the whisker above and the end of the whisker below represent the maximum and the minimum, respectively. The relatively clean, medium, and polluted are defined according to the values of total AOD. All AOD data are derived from MERRA-2.

\subsection{Response of CG Lightning to Total AOD and Thermodynamic Factors}

The lightning activity is also controlled by thermodynamic factors. Aerosols may enhance $[22,37,61]$ or suppress [62-64] convection depending on aerosol properties and atmospheric conditions. In this part, the relationships between CG lightning (including CG lightning density and PPCG) and thermodynamic factors (CAPE and SRH) over the study regions are investigated. The effects of aerosol on CG lightning are further analyzed by control the values of CAPE and SRH.

Figure 6 shows CG lightning density as a function of CAPE and SRH. The mean CG lightning density in each CAPE and SRH bin is marked by a red dot and solid line. The percentage of data number in each CAPE and SRH bin is also marked by a black triangle and dotted line. The data number of each box are provided in Table A2. CAPE ranges from 0 to $1200 \mathrm{Jkg}^{-1}$ over R1 and R3, and ranges from 0 to $1500 \mathrm{Jkg}^{-1}$ over R2. The data over the 
three study regions are mainly concentrated under the conditions with CAPE ranges from 0 to $900 \mathrm{Jkg}^{-1}$. A positive correlation ( $\left.\mathrm{R} 1: \mathrm{R}=64, \mathrm{R} 2: \mathrm{R}=0.54, \mathrm{R} 3: \mathrm{R}=0.55\right)$ between CAPE and $C G$ lightning density can be found in all three study regions (Figure $6 \mathrm{a}-\mathrm{c}$ ). The value of SRH in R1 is the largest among the three study regions and distributes in a narrow range (66.9-81.3\%). The ranges of SRH in R2 (51.7-79.9\%) and R3 (37.9-75.1\%) are relatively larger. The CG lightning density is greater in the conditions with relatively higher SRH in R2 $(R=0.42)$ and $R 3(R=0.47)$, but the little relationship between flash density and SRH is seen in $R 1(R=-0.04)$. The response of the CG lightning density to AOD over the three study regions may be related to the effects of aerosol on lightning activity, but also can be the results of the different local climate conditions, which can impact both aerosol loadings and lightning activity. CAPE, as an indicator of atmospheric instability, was found positively correlated with lighting activities in many other regions throughout the world $[34,35,44]$. The positive relationships between CAPE and CG lightning density found in this study are consistent with these researches. The different relationships between CG lightning density and SRH over the three study regions may be related to the different ranges of SRH. Xiong et al. [36] found that lightning activities respond to SRH with a turning point of about $72-74 \%$. The value of SRH in R1 is concentrated near this threshold. Therefore, the CG lightning density in R1 is not sensitive to SRH. The values of SRH in R2 and R3 are lower than this threshold, and thus the CG lightning density in these two regions is positively correlated with SRH. Figure 7 shows PPCG as a function of CAPE and SRH. The mean CG lightning density and percentage of data number in each CAPE and SRH bin are also marked in each panel as the same in Figure 6. The data number of each box are provided in Table A3. The correlation coefficients between PPCG and CAPE (SRH) over the three study regions are weaker than those between CG lightning density and CAPE (SRH). Weakly negative correlations ( $R 1: R=-0.31, R 2: R=-0.26, R 3: R=-0.32$ ) are found between PPCG and CAPE over the three study regions. A weak correlation is found between PPCG and SRH over $R 1(R=0.09)$ and $R 2(R=-0.24)$, while a moderately negative correlation is found between them over $\mathrm{R} 3(\mathrm{R}=-0.54)$. In addition, the relationships between PPCG and CAPE (SRH) over the three study regions are contrary to those between CG lightning density and CAPE (SRH).

Figure 8 shows the scatter plots of total AOD with CG lightning density and PPCG over the three study regions during 2010-2018. Data from all seasons are included. Weak correlations can be found between CG lightning density and total AOD over R1 ( $R=-0.15)$ and $R 2(R=-0.13)$, while a moderately positive correlation $(R=0.43)$ is found over $R 3$. Weak correlations can be found between PPCG and total AOD over R1 $(R=-0.06)$ and $R 2(R=0.02)$. However, a moderately negative correlation $(R=-0.35)$ is found between them over R3. In fact, the relationships between CG lightning density (PPCG) and total AOD over the three study regions, which are shown in Figure 8, cannot reflect the true relationships between them because of the joint effects of thermodynamic factors. In the following contents, we will try to reduce the effects of thermodynamic factors (CAPE and SRH) by analyzing the relationships between CG lighting density (PPCG) and total AOD for various bins of CAPE and SRH.

Figure 9 shows the CG lightning flashes as a function of CAPE under clean (blue), medium (black), and polluted (red) conditions according to total AOD. The method to define the clean, medium, and polluted conditions is described in Section 2.3. To control the effects of SRH, two ranges of SRH that concentrate most of the samples in each study region are selected. In general, the CG lighting density is higher in medium and polluted conditions compared to that in clean conditions over the three study regions, but this difference is small in R2 (Figure 9a-c). In addition, CG lightning density is more sensitive to CAPE under medium and polluted conditions, especially in R1 and R3. Different from CG lightning density, PPCG under clean conditions is larger than that under medium or polluted conditions, especially in R1 and R2 (Figure 9d-f). 

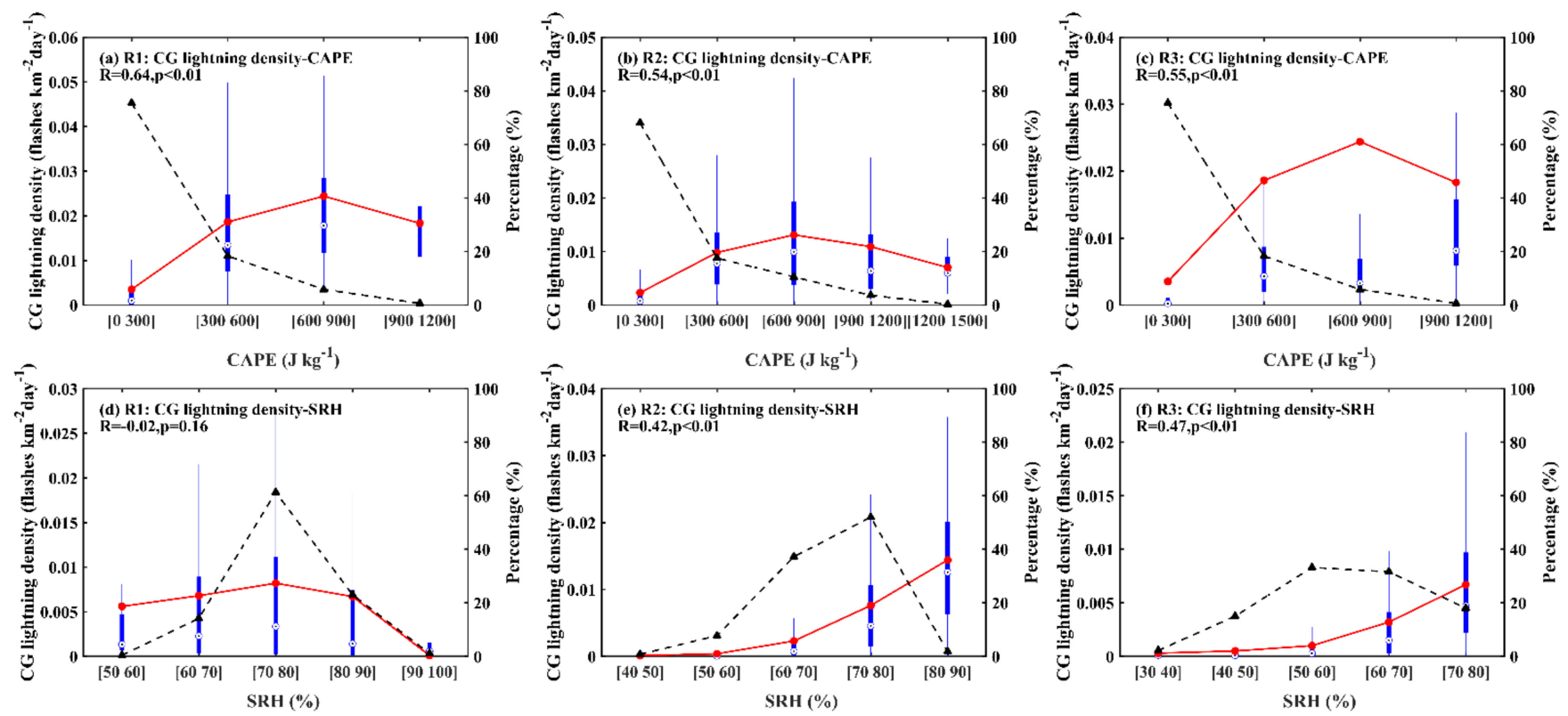

Figure 6. Box plots of CG lightning density (unit: flashes $\mathrm{km}^{-2} \mathrm{day}^{-1}$ ) dispersion showing the relationship between the CG lightning density and two thermodynamic factors (derived from ERA5): (a) (c) CAPE and (d) (f) SRH over the three study regions during 2010-2018. Box plots represent the 25th to 75th percentile of the data in this box (the distance between the bottom and the top of the box), the median (the white circle in each box), the maximum (the end of the whisker above), and the minimum (the end of the whisker below). The red dot in each box represents the mean. The black dot represents the percentage of data points in each bin of CAPE or SRH to the total data point. The Pearson correlation coefficients (R) and $p$ values are also presented in each panel. Data from all seasons are included.
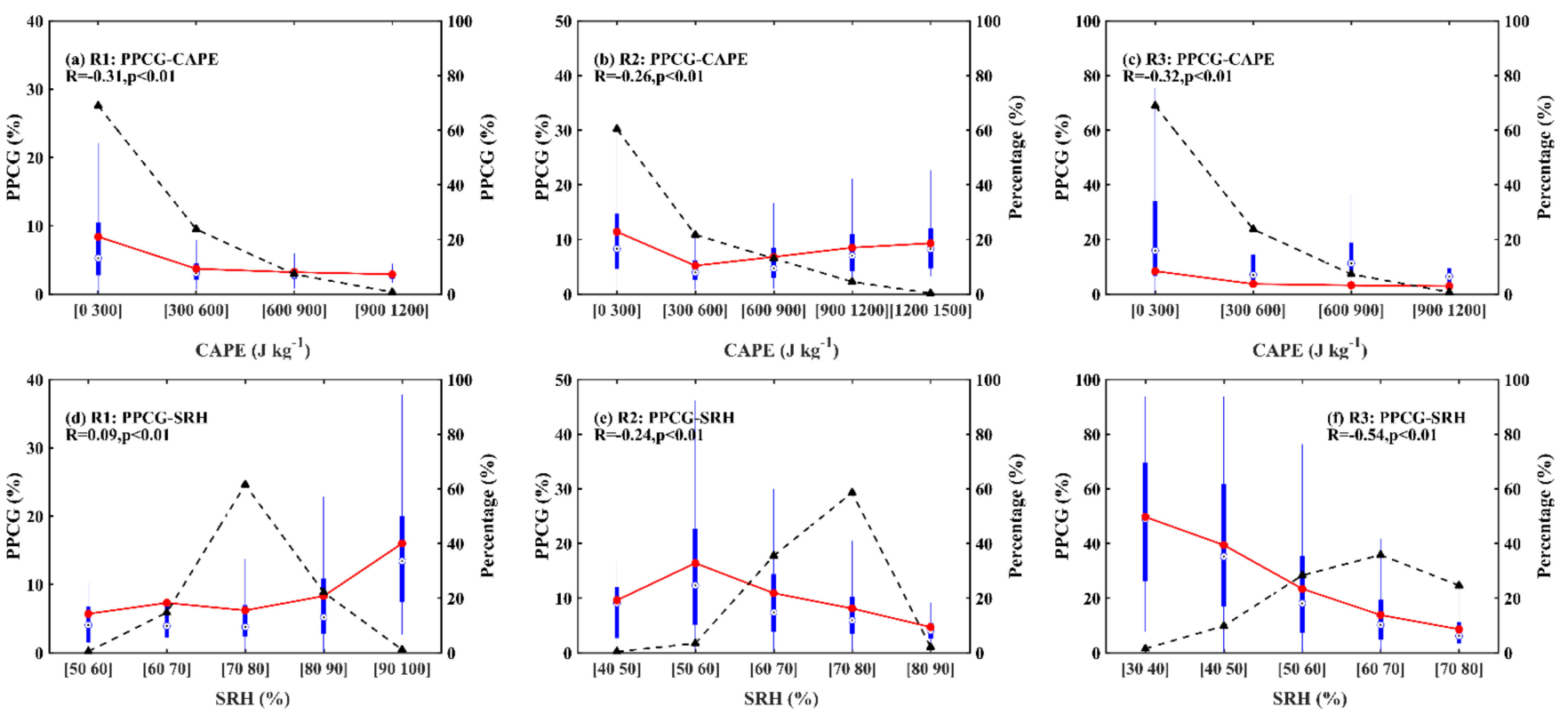

Figure 7. Box plots of PPCG dispersion showing the relationship between the PPCG and two thermodynamic factors (derived from ERA5): (a) (c) CAPE and (d) (f) SRH over the three study regions during 2010-2018. Box plots represent the 25th to 75th percentile of the data in this box (the distance between the bottom and the top of the box), the median (the white circle in each box), the maximum (the end of the whisker above), and the minimum (the end of the whisker below). The red dot in each box represents the mean. The black dot represents the percentage of data points in each bin of CAPE or $\mathrm{SRH}$ to the total data point. The Pearson correlation coefficients $(\mathrm{R})$ and $\mathrm{p}$ values are also presented in each panel. Data from all seasons are included. 

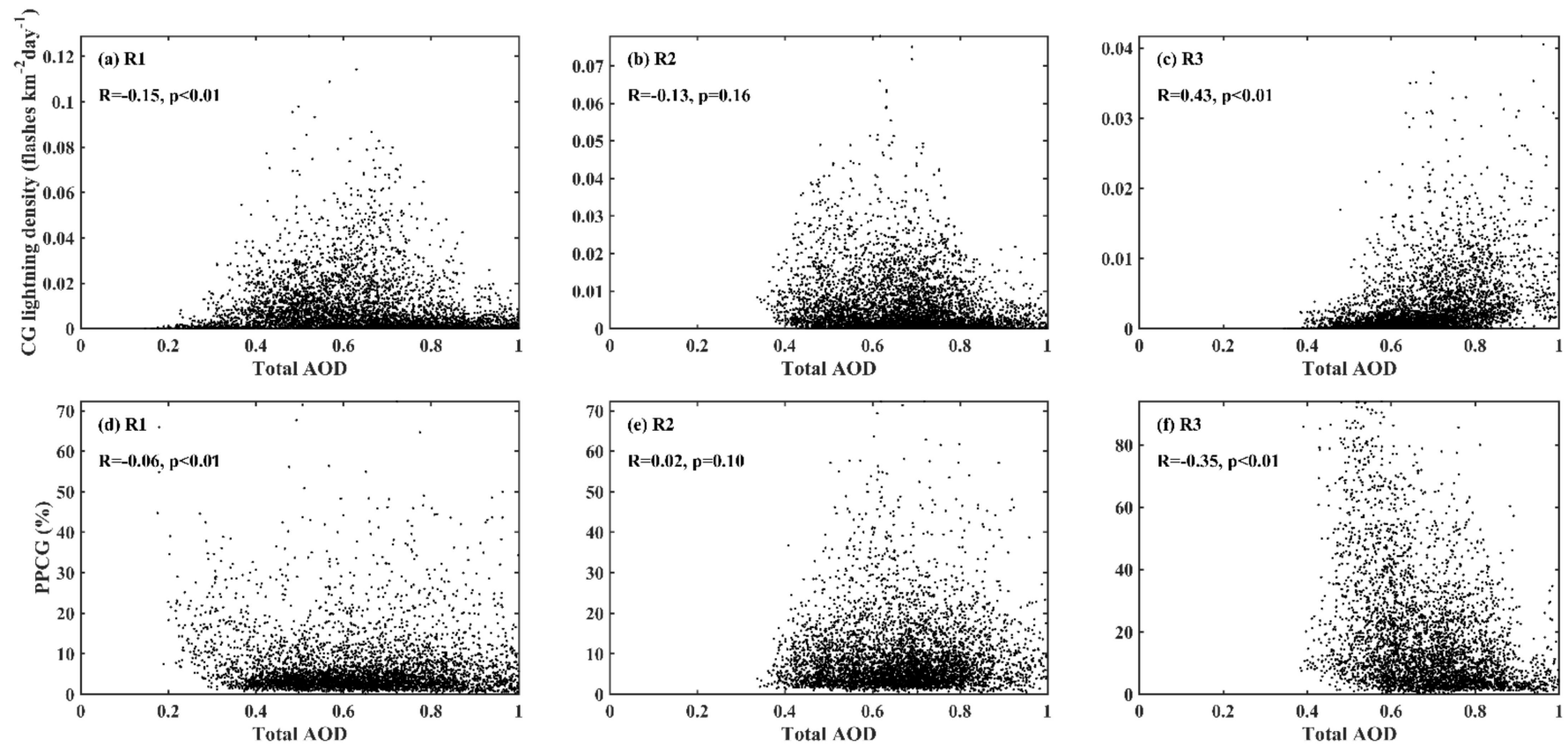

Figure 8. Scatter plots of total AOD with (a)-(c) CG lightning density (flashes $\mathrm{km}^{-2} \mathrm{day}^{-1}$ ) and (d)-(f) PPCG (\%) over three study regions during 2010-2018. Values of correlation coefficients (R) and significance level (p) are also given in each panel. Data from all seasons are included.
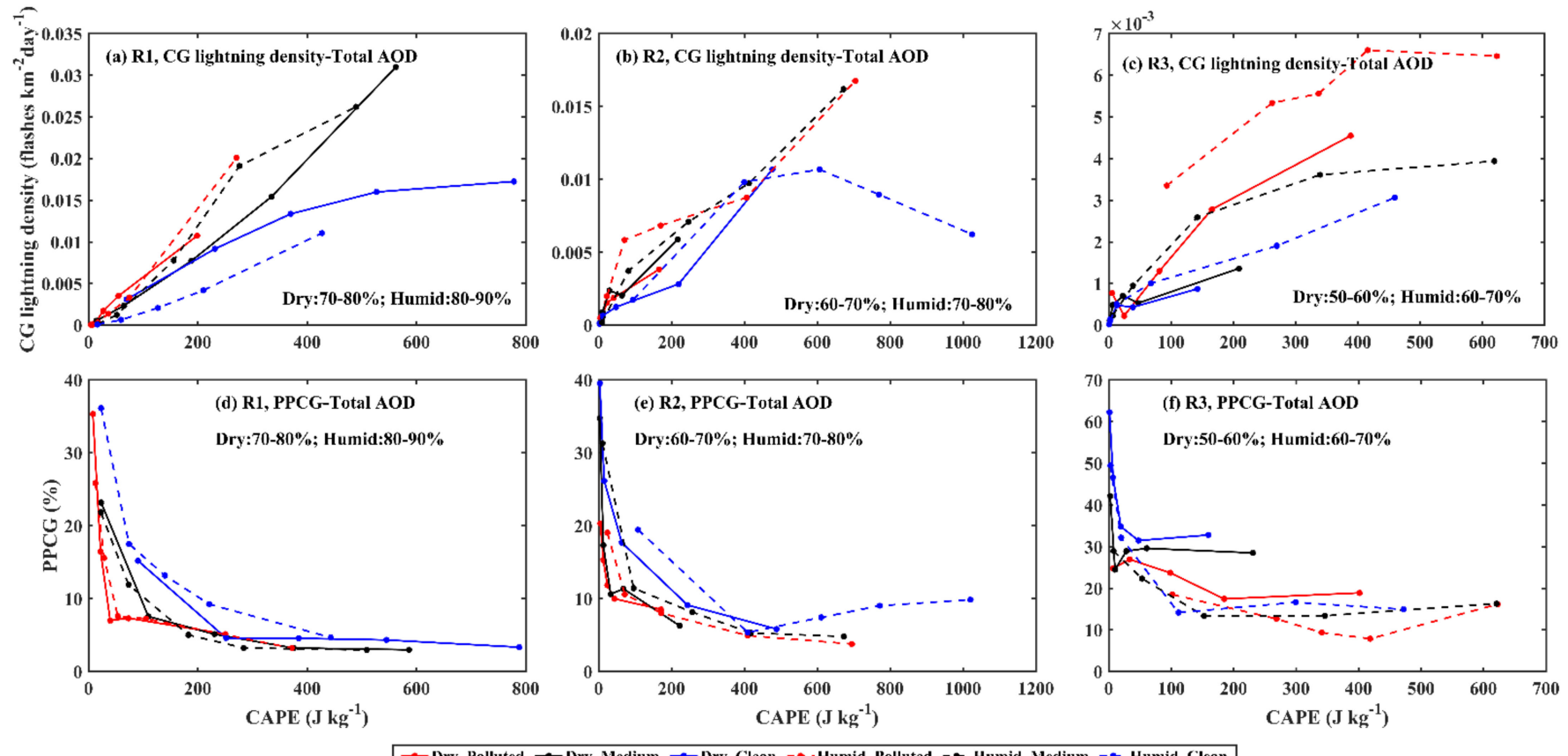

Figure 9. (a) (c) Mean CG lightning density (unit: flashes $\mathrm{km}^{-2} \mathrm{day}^{-1}$ ) and (d) (f) PPCG (\%) as a function of CAPE for clean (blue), medium (black), and polluted (red) conditions for three study regions during 2010-2018. These relationships are investigated under two SRH conditions in each study region. The selected SRH ranges in R1 are 70-80\% and 80-90\%, while that in R2 are $60-70 \%$ and $70-80 \%$, and in R3 are $50-60 \%$ and $60-70 \%$. The clean, medium, and polluted conditions are defined according to total AOD. Data from all seasons are included. The data of CAPE and SRH are derived from ERA5, and AOD data are derived from MERRA-2.

The correlation coefficients between total AOD and CG lightning density or PPCG for various bins of CAPE and SRH are investigated in Figure 10. In R1, the CG lightning density is positively correlated with total AOD when CAPE is around $500-800 \mathrm{Jkg}^{-1}$, 
and SRH is around $70-80 \%$. When SRH is higher than $80 \%$, the total AOD is positively correlated with the CG lightning density in most conditions, but their correlation is stronger in relatively high CAPE conditions. In R2, the CG lightning density is positively correlated with total AOD when CAPE is around $700-1200 \mathrm{Jkg}^{-1}$, and SRH is around $70-80 \%$. In R3, the CG lightning density is positively correlated with the total AOD in most conditions, but their correlations are weaker. Different from the relationship between total AOD and CG lightning density, PPCG is negatively correlated with the total AOD under most conditions over the three study regions. These results are consistent with those found in Figure 9.
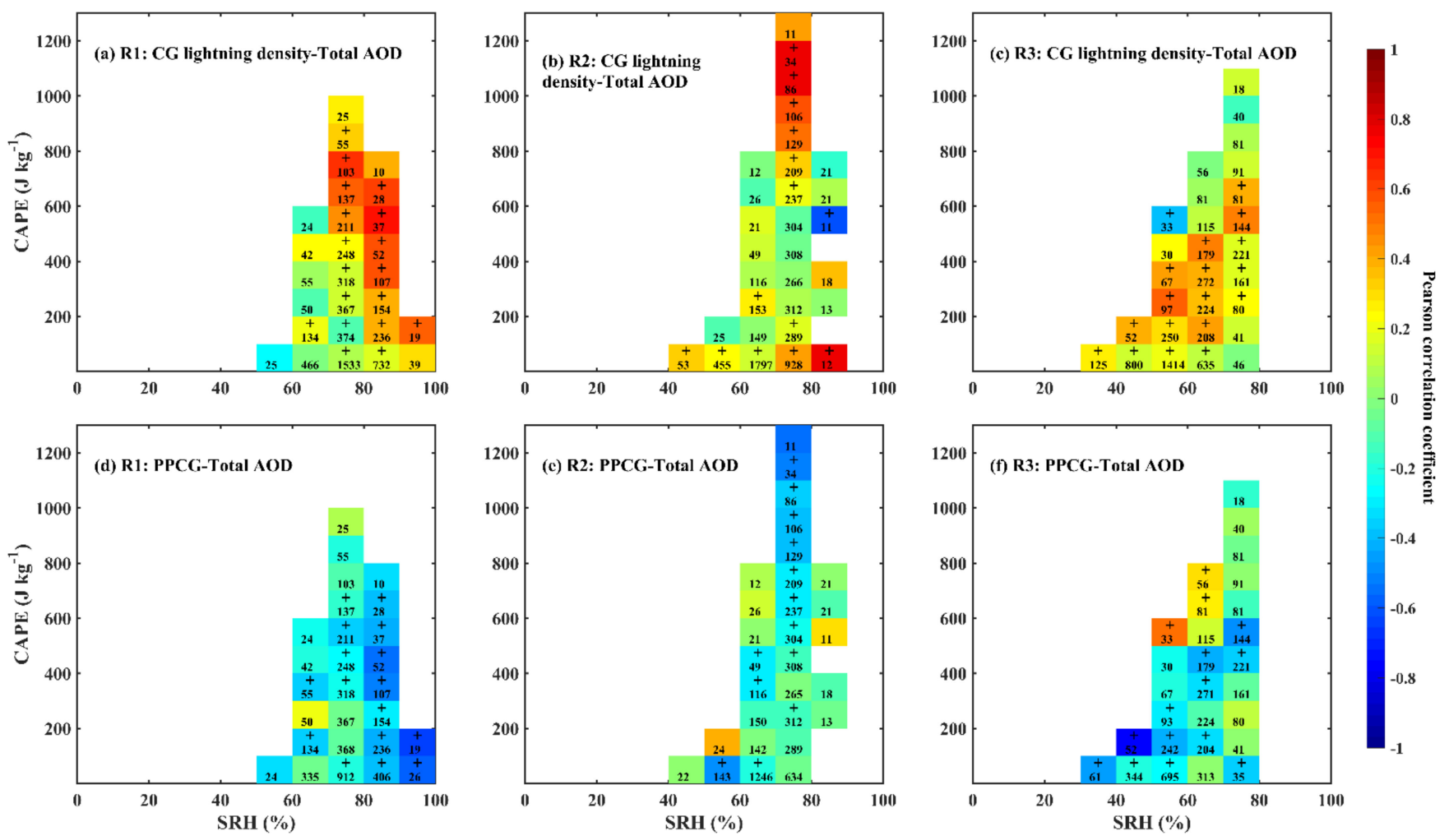

Figure 10. The Pearson correlation coefficients of (a) (c) total AOD-CG lightning density and (d) (f) total AOD-PPCG for various bins of CAPE and SRH over three study regions during 2010-2018. The number in each cell indicates the number of data points in the cell. Plus signs denote those cells that pass the significance test of 0.05 . Data from all seasons are included. The data of CAPE and SRH are derived from ERA5, and AOD data are derived from MERRA-2.

\section{Discussions}

In this paper, the relationships between cloud-to-ground (CG) lighting and aerosols are investigated, as well as their dependences of convective available potential energy (CAPE) and surface relative humidity (SRH), over three air-polluted urban areas (R1: $28^{\circ} \sim 32^{\circ} \mathrm{N}$, $103^{\circ} \sim 107^{\circ} \mathrm{E}, \mathrm{R} 2: 2^{\circ} \sim 33^{\circ} \mathrm{N}, 111^{\circ} \sim 115^{\circ} \mathrm{E}$, and $\mathrm{R} 3: 34^{\circ} \sim 38^{\circ} \mathrm{N}, 115^{\circ} \sim 119^{\circ} \mathrm{E}$ ) of China during 2010-2018.

The interannual variations of CG lightning density and total AOD are all found with a significantly decreasing trend over the three study regions during the study period. We assume the decrease in AOD is related to the decrease in human emissions in recent years. The aerosols over the study regions mainly come from human emissions. Considering the vital impacts of aerosol on lighting activity, the decreasing of AOD may be one of the reasons for the decline in CG lightning over the three study regions. The long-term relationships between aerosols and lightning activity are reported in other regions of China [39,41-43]. The summer lightning activity was found to be suppressed by dramatically increasing aerosol loading, which was caused by anthropogenic pollution due to the rapid economic growth in China, in central China, during 1961-2001 [42]. In the plain regions of southeast China, Yang et al. [43] found the thunderstorms and lightning activities are significantly 
increasing, while regional mean visibility has decreased markedly during 1998-2012. The inverse relationships between aerosol and lightning in these two regions may be due to the different aerosol types in the two places. Central China is dominated by absorbing aerosols, and southeast China is dominated by weak absorbing but strongly hydrophilic aerosols. Our findings in this study are similar to those found by Yang [43] in regions of southeast China.

The relationships between total AOD and CG lightning density PPCG are investigated after controlling the value of CAPE and SRH. Results show that the CG lightning density is larger under medium or polluted conditions, especially in R1 and R3. However, PPCG is larger under clean conditions. The correlations of AOD-CG lightning density show AOD is positively correlated with CG lightning density under most conditions over the three study regions but is negatively correlated with PPCG. Some modeling studies have shown that CAPE and relative humidity can modulate the amount that aerosols invigorate convective clouds [65-67]. The results in Figure 9 show that the CG lightning density is more sensitive to CAPE under conditions with more aerosols. The results in Figure 10 show that the positive correlations between AOD and CG lightning density are stronger under high CAPE or SRH conditions, but this result is insignificant in R3. However, they both support the generalizations that in these three study regions, adding aerosols in the background concentration could enhance the CG lightning density.

Different from CG lightning density, our results suggest that PPCG is negatively correlated with AOD. The negative relationships between PPCG and urban aerosol loading were reported in many other regions, such as Southeastern Brazil [12], South Korea [14], Texas [68], and Taipei [15]. However, some studies also found that smoke from forest fires tends to produce more positive CG lightning [9-11]. Tan et al. [44] also reported a positive relationship between PPCG and AOD in Nanjing (China). These previous findings, as well as the results found in this study, suggest that the possible effects of aerosols on PPCG are complicated, and there may be a dependence on aerosol types, concentration, and local meteorological conditions. The types of lightning are tightly correlated with the distribution of space charge of thunderstorms [69,70]. Previous studies have figured out that there is one main positive charge center above the main negative charge center, and one smaller positive charge center exists under the main negative charge center in most thunderstorms, which is named as the triple structure [71,72]. Jayaratne et al. [25] found that the graupel is charged negatively for all temperatures $\left(-6^{\circ} \mathrm{C} \sim-25^{\circ} \mathrm{C}\right)$ after impurities are involved in the cloud. The charge reversal temperature $\left(-25^{\circ} \mathrm{C}\right)$ will increase to a higher temperature if the cloud droplets contained a small amount of contaminant. This will expand the region of the main negative charge center to the lower region of the cloud, covering the positive charge center below. This new structure of the thunderstorm may generate more negative CG flashes, decreasing the percentage of positive CG flashes. However, Avila et al. [73] found that the graupel is charged positively over most of the temperature range $\left(-10{ }^{\circ} \mathrm{C} \sim-25^{\circ} \mathrm{C}\right)$ under conditions with smaller droplets and is charged negatively at temperatures below $-18^{\circ} \mathrm{C}$ under conditions with larger droplets. This means that under conditions with high $\mathrm{CCN}$, namely, the cloud droplet is smaller, the positively charged center in a thunderstorm will be intensified. Therefore, a more specific analysis is required to explain the effects of aerosols on lightning characteristics.

\section{Conclusions}

In this study, nine years (2010-2018) of data of CG lightning and total AOD over three air-polluted urban regions (R1: $28^{\circ} \sim 32^{\circ} \mathrm{N}, 103^{\circ} \sim 107^{\circ} \mathrm{E}$; R2: $29^{\circ} \sim 33^{\circ} \mathrm{N}, 111^{\circ} \sim 115^{\circ} \mathrm{E}$; R3: $34^{\circ} \sim 38^{\circ} \mathrm{N}, 115^{\circ} \sim 119^{\circ} \mathrm{E}$ ) of China are mainly analyzed. The main results are as follows.

1. Over all study regions, an apparent enhancement in CG lightning density is found under high AOD conditions on seasonal cycles during the study period. Decreasing trends are both found in the interannual variations of CG lightning density and total AOD over the three study regions during the study period; 
2. In various values of CAPE and SRH, CG lightning density is larger under conditions with high total AOD than that under conditions with low total AOD, but PPCG is smaller under conditions with high total AOD than that under conditions with low total AOD. In addition, CG lightning density is more sensitive to CAPE under conditions with high total AOD;

3. CG lightning density is positively correlated with total AOD in some bins of CAPE and SRH, while PPCG is negatively correlated with total AOD in most bins of CAPE and SRH.

The processes involved in producing lightning and their associations with aerosols are quite complicated. In this paper, we obtain a rough relationship between aerosols and CG lighting over three study regions based on observations alone. More analyses based on a combination of state-of-the-art observations and simulations are warranted in the future.

Author Contributions: Conceptualization, H.W. (Haichao Wang), Y.T., and Z.S.; methodology, H.W. (Haichao Wang), X.W., and L.L.; validation, Z.S.; investigation, H.W. (Haichao Wang) and X.L.; data curation, H.W. (Haichao Wang), X.W., and L.L.; writing-original draft preparation, H.W. (Haichao Wang); writing-review and editing, H.W. (Honglei Wang) and Z.S. All authors have read and agreed to the published version of the manuscript.

Funding: This research was funded by the National Natural Science Foundation of China, grant number "41805002"; the Natural Science Foundation of Jiangsu Province, (grant number "BK20180805" "BK20180808"," BK20190147"); the Natural Science Fundamental Research Project of Jiangsu Colleges and Universities, (grant number "19KJB170025"); the Open Grants of the State Key Laboratory of Severe Weather, (grant number "2021LASW-B05"); and the Undergraduate Innovation Project of NUIST, (grant number “201910300160”).

Institutional Review Board Statement: Not applicable.

Informed Consent Statement: Not applicable.

Data Availability Statement: The cloud-to-ground lightning data presented in this study are available on request from the corresponding author. AOD data can be found here: [https://cds. climate.copernicus.eu/\#!/search?text=ERA5] and thermodynamic factors data can be found here: [https://search.earthdata.nasa.gov/search].

Acknowledgments: We appreciate the support of the European Centre for Medium-Range Weather Forecasts (ECMWF) in providing reanalysis meteorological data, NASA in providing MERRA-2 AOD data, and China Meteorological Administration (CMA) and China National Meteorological Center (CNMC) in providing cloud-to-ground lightning data. In addition, we sincerely appreciate all the anonymous reviewers for their excellent comments and efforts.

Conflicts of Interest: The authors declare no conflict of interest. 


\section{Appendix A}
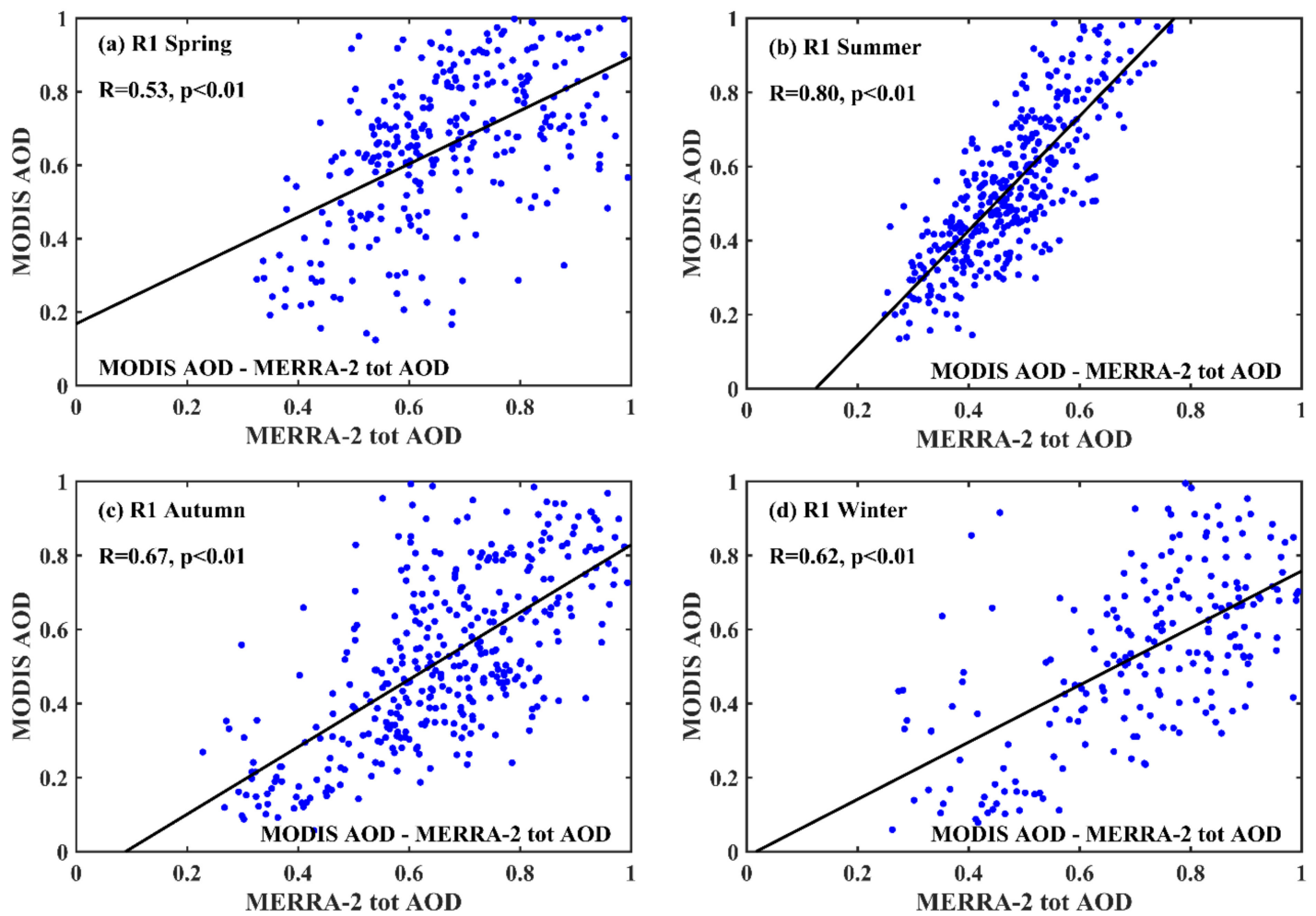

Figure A1. Scattered plots of monthly MODIS AOD (550 nm) and MERRA-2 total AOD (550 nm) for four seasons (spring: March, April, and May; summer: June, July, and August; autumn: September, October, and November; winter: January, February, and December) over R1 during 2010-2018. Values of correlation coefficients (R) and significance level (p) are also given in each panel.
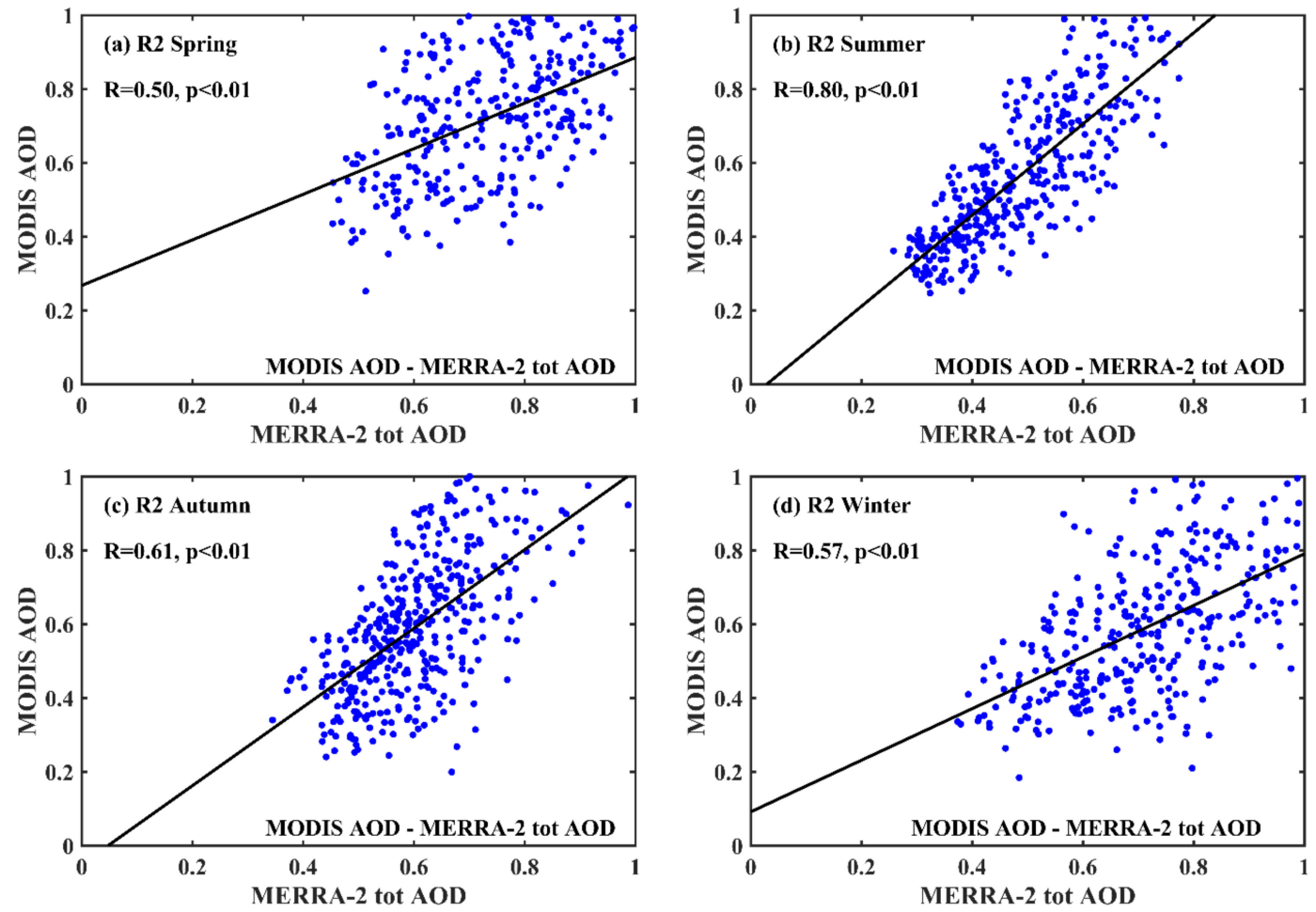

Figure A2. Same as in Figure A1, but for R2. 

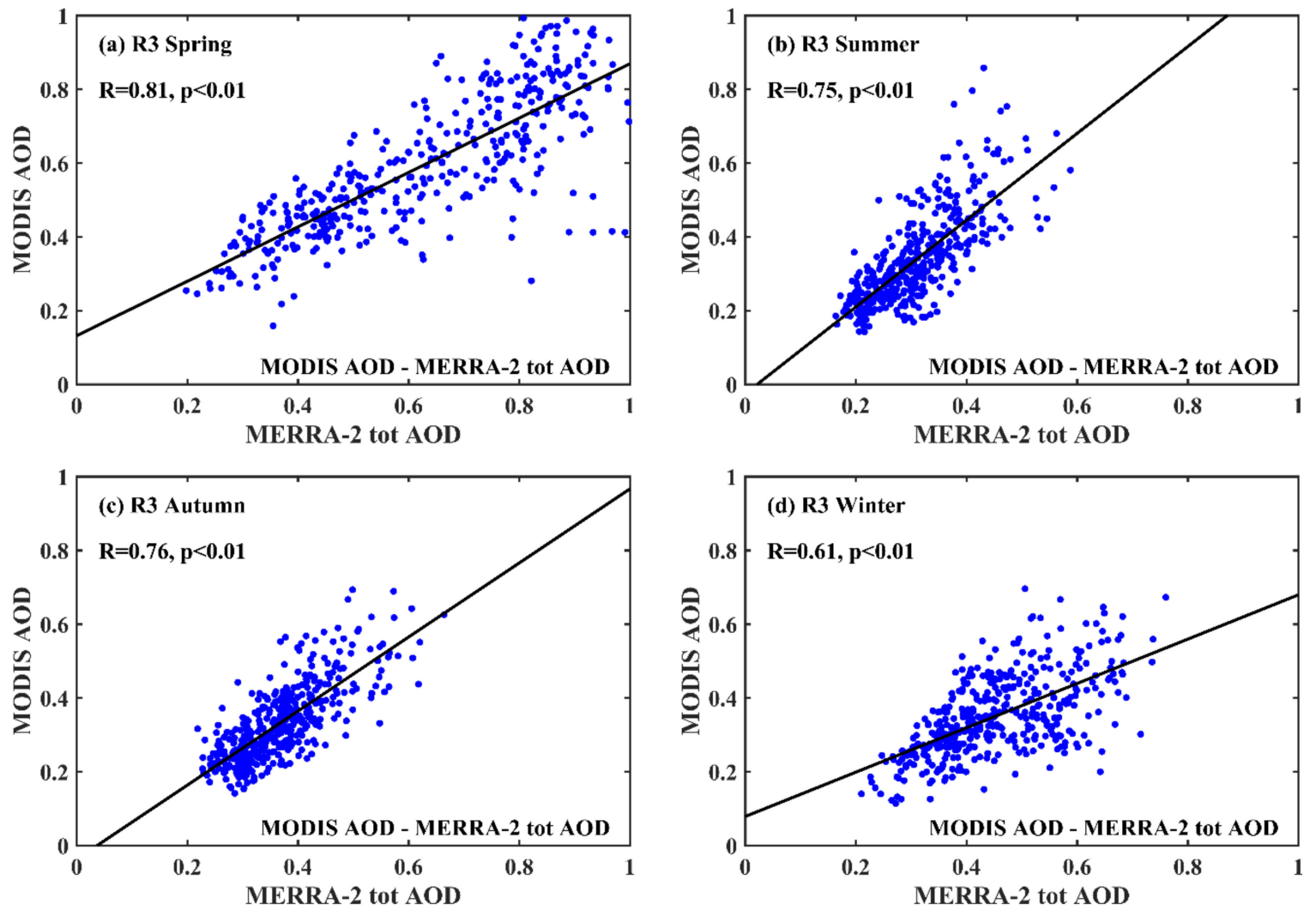

Figure A3. Same as in Figure A1, but for R3.

Table A1. The data number in each condition of each month over R1, R2, and R3.

\begin{tabular}{|c|c|c|c|c|c|c|c|c|c|c|c|c|}
\hline & 1 & 2 & 3 & 4 & 5 & 6 & 7 & 8 & 9 & 10 & 11 & 12 \\
\hline R1 & 49 & 125 & 150 & 181 & 192 & 192 & 192 & 192 & 192 & 188 & 148 & 67 \\
\hline $\mathrm{R} 2$ & 129 & 165 & 184 & 192 & 192 & 192 & 192 & 192 & 192 & 188 & 132 & 114 \\
\hline R3 & 50 & 144 & 189 & 192 & 192 & 192 & 181 & 186 & 192 & 183 & 120 & 60 \\
\hline
\end{tabular}

Table A2. The data number in each box.

\begin{tabular}{|c|c|c|c|c|c|c|}
\hline CG Lightning Density-CAPE & 1 & 2 & 3 & 4 & 5 & Sum \\
\hline $\mathrm{R} 1$ & 4517 & 1095 & 346 & 33 & - & 5991 \\
\hline $\mathrm{R} 2$ & 4272 & 1102 & 662 & 228 & 17 & 6281 \\
\hline R3 & 3977 & 1271 & 397 & 59 & - & 5704 \\
\hline CG Lightning Density-SRH & 1 & 2 & 3 & 4 & 5 & Sum \\
\hline R1 & 26 & 850 & 3673 & 1376 & 66 & 5991 \\
\hline $\mathrm{R} 2$ & 53 & 486 & 2366 & 3264 & 112 & 6281 \\
\hline R3 & 125 & 857 & 1891 & 1803 & 1028 & 5704 \\
\hline
\end{tabular}


Table A3. The data number in each box.

\begin{tabular}{|c|c|c|c|c|c|c|}
\hline PPCG-CAPE & 1 & 2 & 3 & 4 & 5 & Sum \\
\hline R1 & 3267 & 1095 & 346 & 33 & - & 4741 \\
\hline $\mathrm{R} 2$ & 3065 & 1101 & 662 & 228 & 17 & 5073 \\
\hline R3 & 2408 & 1270 & 397 & 59 & - & 4134 \\
\hline PPCG-SRH & 1 & 2 & 3 & 4 & 5 & Sum \\
\hline R1 & 25 & 697 & 2917 & 1049 & 53 & 4741 \\
\hline $\mathrm{R} 2$ & 22 & 174 & 1800 & 2972 & 105 & 5073 \\
\hline R3 & 51 & 407 & 1170 & 1479 & 1017 & 4134 \\
\hline
\end{tabular}

\section{References}

1. Krause, A.; Kloster, S.; Wilkenskjeld, S.; Paeth, H. The sensitivity of global wildfires to simulated past, present, and future lightning frequency. J. Geophys. Res. 2014, 119, 312-322. [CrossRef]

2. Abdollahi, M.; Dewan, A.M.; Hassan, Q.K. Applicability of remote sensing-based vegetation water content in modeling lightningcaused forest fire occurrences. ISPRS Int. J. Geo-Inf. 2019, 8, 143. [CrossRef]

3. Holle, R.L.; Dewan, A.; Said, R.; Brooks, W.A.; Hossain, M.F.; Rafiuddin, M. Fatalities related to lightning occurrence and agriculture in Bangladesh. Int. J. Disaster Risk Reduct. 2019, 41, 101264. [CrossRef]

4. Zhang, W.; Meng, Q.; Ma, M.; Zhang, Y. Lightning Casualties and Damages in China from 1997 to 2009. Nat. Hazards 2011, 57, 465-476. [CrossRef]

5. Westcott, N.E. Summertime Cloud-to-Ground lightning activity around major midwestern urban areas. J. Appl. Meteorol. Clim. 1995, 34, 1633-1642. [CrossRef]

6. Altaratz, O.; Koren, I.; Yair, Y.; Price, C. Lightning response to smoke from Amazonian fires. Geophys. Res. Lett. 2010, 37, L07801. [CrossRef]

7. Yuan, T.; Remer, L.A.; Pickering, K.E.; Yu, H. Observational evidence of aerosol enhancement of lightning activity and convective invigoration. Geophys. Res. Lett. 2011, 38, L04701. [CrossRef]

8. Thornton, J.A.; Virts, K.S.; Holzworth, R.H.; Mitchell, T.P. Lightning enhancement over major oceanic shipping lanes. Geophys. Res. Lett. 2017, 44, 9102-9111. [CrossRef]

9. Lyons, W.A.; Nelson, T.E.; Williams, E.R.; Cramer, J.A.; Turner, T.R. Enhanced positive cloud-to-ground lightning in thunderstorms ingesting smoke from fires. Science 1998, 282, 77-80. [CrossRef] [PubMed]

10. Murray, N.D.; Orville, R.E.; Huffines, G.R. Effect of pollution from Central American fires on cloud-to-ground lightning in May 1998. Geophys. Res. Lett. 2000, 27, 2249-2252. [CrossRef]

11. Lang, T.J.; Rutledge, S.A. Cloud-to-ground lightning downwind of the 2002 Hayman forest fire in Colorado. Geophys. Res. Lett. 2006, 33, L03804. [CrossRef]

12. Naccarato, K.P.; Pinto, O., Jr.; Pinto, I.R.C.A. Evidence of thermal and aerosol effects on the cloud-to-ground lightning density and polarity over large urban areas of Southeastern Brazil. Geophys. Res. Lett. 2003, 30, 1674. [CrossRef]

13. Steiger, S.M.; Orville, R.E. Cloud-to-ground lightning enhancement over Southern Louisiana. Geophys. Res. Lett. 2003, 30 , 1975. [CrossRef]

14. Kar, S.K.; Liou, Y.A.; Ha, K.J. Aerosol effects on the enhancement of cloud-to-ground lightning over major urban areas of South Korea. Atmos. Res. 2009, 92, 80-87. [CrossRef]

15. Kar, S.K.; Liou, Y.A. Enhancement of cloud-to-ground lightning activity over Taipei, Taiwan in relation to urbanization. Atmos. Res. 2014, 147, 111-120. [CrossRef]

16. Lal, D.M.; Pawar, S.D. Effect of urbanization on lightning over four metropolitan cities of India. Atmos. Environ. 2011, 45, 191-196. [CrossRef]

17. Hu, J.; Rosenfeld, D.; Ryzhkov, A.; Zrnic, D.; Williams, E.; Zhang, P.; Snyder, J.C.; Zhang, R.; Weitz, R. Polarimetric Radar Convective Cell Tracking Reveals Large Sensitivity of Cloud Precipitation and Electrification Properties to CCN. J. Geophys. Res. 2019, 124, 12194-12205. [CrossRef]

18. Li, Z.; Rosenfeld, D.; Fan, J. Aerosols and their impact on radiation, clouds, precipitation, and severe weather events. In Oxford Research Encyclopedia Environmental Science; Oxford University Press: Cary, NC, USA, 2017. [CrossRef]

19. Rosenfeld, D.; Itamar, M.L. Satellite-based insights into precipitation formation processes in continental and maritime convective clouds. Bull. Am. Meteorol. Soc. 1998, 79, 2457-2476. [CrossRef]

20. Rosenfeld, D.; Lohmann, U.; Raga, G.B.; O’Dowd, C.D.; Kulmala, M.; Fuzzi, S.; Reissell, A.; Andreae, M.O. Flood or drought: How do aerosols affect precipitation? Science 2008, 321, 1309-1313. [CrossRef]

21. Fan, J.; Leung, L.R.; Rosenfeld, D.; Chen, Q.; Li, Z.; Zhang, J.; Yan, H. Microphysical effects determine macrophysical response for aerosol impacts on deep convective clouds. Proc. Natl. Acad. Sci. USA 2013, 110, 201316830. [CrossRef] 
22. Khain, A.; Rosenfeld, D.; Pokrovsky, A. Aerosol impact on the dynamics and microphysics of deep convective clouds. Q. J. R. Meteorol. Soc. 2005, 131, 2639-2663. [CrossRef]

23. Tao, W.K.; Chen, J.P.; Li, Z.; Wang, C.; Zhang, C. Impact of aerosols on convective clouds and precipitation. Rev. Geophys. 2012, 50. [CrossRef]

24. Takahashi, T. Riming electrification as a charge generation mechanism in thunderstorms. J. Atmos. Sci. 1978, 35, 1536-1548. [CrossRef]

25. Jayaratne, E.R.; Saunders, C.P.R.; Hallett, J. Laboratory studies of the charging of soft hail during ice crystal interactions. Q. J. R. Meteor. Soc. 1983, 109, 609-630. [CrossRef]

26. Williams, E.R. The Electrification of Thunderstorms. Sci. Am. 1988, 259, 88-99. [CrossRef]

27. Kaufman, Y.J.; Tanré, D.; Holben, B.N.; Mattoo, S.; Remer, L.A.; Eck, T.F.; Vaughan, J.; Chatenet, B. Aerosol radiative impact on spectral solar flux at the surface, derived from principal-plane sky measurements. J. Atmos. Sci. 2002, 59, 635-646. [CrossRef]

28. Koren, I.; Kaufman, Y.J.; Remer, L.A.; Martins, J.V. Measurement of the effect of Amazon smoke on inhibition of cloud formation. Science 2004, 303, 1342-1345. [CrossRef]

29. Koren, I.; Martins, J.V.; Remer, L.A.; Afargan, H. Smoke invigoration versus inhibition of clouds over the Amazon. Science 2008, 321, 946-949. [CrossRef] [PubMed]

30. Siingh, D.; Buchunde, P.S.; Singh, R.P.; Nath, A.; Kumar, S.; Ghodpage, R.N. Lightning and convective rain study in different parts of India. Atmos. Res. 2014, 137, 35-48. [CrossRef]

31. Lal, D.M.; Ghude, S.D.; Mahakur, M.; Waghmare, R.T.; Tiwari, S.; Srivastava, M.K.; Meena, G.S.; Chate, D.M. Relationship between aerosol and lightning over Indo-Gangetic Plain (IGP), India. Clim. Dynam. 2018, 50, 3865-3884. [CrossRef]

32. Rosenfeld, D.; Williams, E.; Andreae, M.O.; Freud, E.; Pöschl, U.; Rennó, N.O. The scientific basis for a satellite mission to retrieve CCN concentrations and their impacts on convective clouds. Atmos. Meas. Tech. 2012, 5, 2039-2055. [CrossRef]

33. Keith, D.S.; Matthew, D.P. Climatology and ingredients of significant severe convection in high-shear, low-CAPE environments. Weather Forecast. 2014, 29, 854-877.

34. Murugavel, P.; Pawar, S.D.; Gopalakrishnan, V. Trends of convective available potential energy over the Indian region and its effect on rainfall. Int. J. Climatol. 2012, 32, 1362-1372. [CrossRef]

35. Dewan, A.; Ongee, E.T.; Rafiuddin, M.; Rahman, M.M.; Mahmood, R. Lightning activity associated with precipitation and CAPE over Bangladesh. Int. J. Climatol. 2018, 38, 1649-1660. [CrossRef]

36. Xiong, Y.J.; Qie, X.S.; Zhou, Y.J.; Yuan, T.; Zhang, Y.L. Regional response of lightning activities to relative humidity of the surface. Chin. J. Geophys. 2006, 49, 367-374. [CrossRef]

37. Fan, J.; Zhang, R.; Li, G.; Tao, W. Effects of aerosols and relative humidity on cumulus clouds. J. Geophys. Res. Atmos. 2007, 112, D14204. [CrossRef]

38. Shi, Z.; Tan, Y.; Liu, Y.; Liu, J.; Lin, X.; Wang, M.; Luan, J. Effects of relative humidity on electrification and lightning discharges in thunderstorms. Terr. Atmos. Ocean. Sci. 2018, 29, 695-708. [CrossRef]

39. Yang, X.; Li, Z.; Liu, L.; Zhou, L.; Cribb, M.; Zhang, F. Distinct weekly cycles of thunderstorms and a potential connection with aerosol type in China. Geophys. Res. Lett. 2016, 43, 8760-8768. [CrossRef]

40. Wang, Q.; Li, Z.; Guo, J.; Zhao, C.; Cribb, M. The climate impact of aerosols on the lightning flash rate: Is it detectable from long-term measurements? Atmos. Chem. Phys. 2018, 18, 12797-12816. [CrossRef]

41. Zhao, P.; Li, Z.; Xiao, H.; Wu, F.; Zheng, Y.; Cribb, M.C.; Jin, X.; Zhou, Y. Distinct aerosol effects on cloud-to-ground lightning in the plateau and basin regions of Sichuan, Southwest China. Atmos. Chem. Phys. 2020, 20, 1-38. [CrossRef]

42. Yang, X.; Yao, Z.; Li, Z.; Fan, T. Heavy air pollution suppresses summer thunderstorms in central China. J. Atmos. Sol. Terr. Phys. 2013, 95, 28-40. [CrossRef]

43. Yang, X.; Li, Z. Increases in thunderstorm activity and relationships with air pollution in southeast China. J. Geophys. Res. 2014, 119, 1835-1844. [CrossRef]

44. Tan, Y.B.; Peng, L.; Shi, Z.; Chen, H.R. Lightning flash density in relation to aerosol over Nanjing (China). Atmos. Res. 2016, $174,1-8$.

45. Wang, Y.; Wan, Q.; Meng, W.; Liao, F.; Tan, H.; Zhang, R. Long-term impacts of aerosols on precipitation and lightning over the Pearl River Delta megacity area in China. Atmos. Chem. Phys. 2011, 11, 12421-12436. [CrossRef]

46. Chen, L.; Tao, M.; Wang, Z.; Tao, J.; Yu, C.; Zhang, Y.; Fan, M.; Gu, J.; Su, L. Satellite record of the transition of air quality over China. Big Earth Data 2018, 2, 190-196. [CrossRef]

47. Cummins, K.L.; Murphy, M.J.; Bardo, E.A.; Hiscox, W.L.; Pyle, R.B.; Prfer, A.E. A combined TOA/MDF technology upgrade of the, U.S. national lightning detection network. J. Geophys. Res. 1998, 103, 9035-9044. [CrossRef]

48. Yang, X.; Sun, J.; Li, W. An analysis of cloud-to-ground lightning in China during 2010-2013. Weather Forecast. 2015, 30, 1537-1550. [CrossRef]

49. Xia, R.; Zhang, D.L.; Wang, B. A 6-yr cloud-to-ground lightning climatology and its relationship to rainfall over central and eastern China. J. Appl. Meteorol. Clim. 2015, 54, 2443-2460. [CrossRef]

50. Cummins, K.L.; Murphy, M.J. An overview of lightning locating systems: History, techniques, and data uses, with an in-depth look at the U.S. NLDN. IEEE Trans. Electromagn. Compat. 2009, 51, 499-518. [CrossRef]

51. Wu, W.-S.; Purser, R.J.; Parrish, D.F. Three-dimensional variational analysis with spatially inhomogeneous covariances. Mon. Weather Rev. 2002, 130, 2905-2916. [CrossRef] 
52. Kleist, D.T.; Parrish, D.F.; Derber, J.C.; Treadon, R.; Wu, W.-S.; Lord, S. Introduction of the GSI into the NCEP Global Data Assimilation System. Weather Forecast. 2009, 24, 1691-1705. [CrossRef]

53. Chin, M. Coauthors, Tropospheric aerosol optical thick ness from the GOCART model and comparisons with satellite and sun photometer measurements. J. Atmos. Sci. 2002, 59, 461-483. [CrossRef]

54. Colarco, P.R.; da Silva, A.; Chin, M.; Diehl, T. Online simulations of global aerosol distributions in the NASA GEOS-4 model and comparisons to satellite and ground-based aerosol optical depth. J. Geophys. Res. 2010, 115, D14207. [CrossRef]

55. Buchard, V.; Randles, C.A.; Silva, A.M.D.; Darmenov, A.; Colarco, P.R.; Govindaraju, R.; Ferrare, R.; Hair, J.; Beyersdorf, A.J.; Ziemba, L.D.; et al. The MERRA-2 aerosol reanalysis, 1980 onward. Part II: Evaluation and case studies. J. Climate. 2017, 30, 6851-6872. [CrossRef] [PubMed]

56. Sun, E.; Xu, X.; Che, H.; Tang, Z.; Gui, K.; An, L.; Lu, C.; Shi, G. Variation in MERRA-2 aerosol optical depth and absorption aerosol optical depth over China from 1980 to 2017. J. Atmos. Sol. Terr. Phys. 2019, 186, 8-19. [CrossRef]

57. Pearson, K., VII. Mathematical contributions to the theory of evolution-III. Regression, heredity, and panmixia. Philos. Trans. R. Soc. Lond. 1896, 187, 253-318.

58. Liu, X.; Chen, Q.; Che, H.; Zhang, R.; Gui, K.; Zhang, H.; Zhao, T. Spatial distribution and temporal variation of aerosol optical depth in the Sichuan basin, China, the recent ten years. Atmos. Environ. 2016, 147, 434-445. [CrossRef]

59. Li, X.; Pan, Y.; Mo, Z. Joint Effects of Several Factors on Cloud-to-Ground Lightning and Rainfall in Nanning (China). Atmos. Res. 2018, 212, 23-32. [CrossRef]

60. Shi, Z.; Wang, H.; Tan, Y.; Li, L.; Li, C. Influence of Aerosols on Lightning Activities in Central Eastern Parts of China. Atmos. Sci. Lett. 2020, 21, e957. [CrossRef]

61. Khain, A.P.; BenMoshe, N.; Pokrovsky, A. Factors Determining the Impact of Aerosols on Surface Precipitation from Clouds: An Attempt at Classification. J. Atmos. Sci. 2008, 65, 1721-1748. [CrossRef]

62. Rosenfeld, D.; Rudich, Y.; Lahav, R. Desert dust suppressing precipitation: A possible desertification feedback loop. Proc. Natl. Acad. Sci. USA 2001, 98, 5975-5980. [CrossRef] [PubMed]

63. Khain, A.; Pokrovsky, A.; Pinsky, M.; Seifert, A.; Phillips, V. Simulation of effects of atmospheric aerosols on deep turbulent convective clouds using a spectral microphysics mixed-phase cumulus cloud model. Part I: Model description and possible applications. J. Atmos. Sci. 2004, 61, 2963-2982. [CrossRef]

64. Zhao, C.; Tie, X.; Lin, Y. A possible positive feedback of reduction of precipitation and increase in aerosols over eastern central China. Geophys. Res. Lett. 2006, 33, L11814. [CrossRef]

65. Khain, A.P. Notes on state-of-the-art investigations of aerosol effects on precipitation: A critical review. Environ. Res. Lett. 2009, 4, 015004. [CrossRef]

66. Lee, S.S. Dependence of aerosol-precipitation interactions on humidity in a multiple-cloud system. Atmos. Chem. Phys. 2011, 11, 2179-2196. [CrossRef]

67. Fan, J.; Yuan, T.; Comstock, J.M.; Ghan, S.; Khain, A.; Leung, L.R.; Li, Z.Q.; Martins, M.J.; Ovchinnikov, M. Dominant role by vertical wind shear in regulating aerosol effects on deep convective clouds. J. Geophys. Res. Atmos. 2009, 114, D22206. [CrossRef]

68. Steiger, S.M.; Orville, R.E.; Huffines, G. Cloud-to-ground lightning characteristics over Houston, Texas: 1989-2000. J. Geophys. Res. 2002, 107, 4117. [CrossRef]

69. Zhao, P.; Yin, Y.; Xiao, H. The effects of aerosol on development of thunderstorm electrification: A numerical study. Atmos. Res. 2015, 153, 376-391. [CrossRef]

70. Tan, Y.; Tao, S.; Liang, Z.; Zhu, B. Numerical study on relationship between lightning types and distribution of space charge and electric potential. J. Geophys. Res. 2014, 119, 1003-1014. [CrossRef]

71. Marshall, T.C.; Rust, W.D. Electric field soundings through thunderstorms. J. Geophys. Res. 1991, 96, 22297-22306. [CrossRef]

72. Siingh, D.; Singh, A.K.; Patel, R.P.; Singh, R.; Singh, R.P.; Veenadhari, B.; Mukherjee, M. Thunderstorms, lightning, sprites and magnetospheric whistler-mode radio waves. Surv. Geophys. 2008, 29, 499-551. [CrossRef]

73. Avila, E.E.; Pereyra, R.G.; Varela, G.G.A.; Caranti, G.M. The effect of the cloud-droplet spectrum on electrical-charge transfer during individual ice-ice collisions. Q. J. R. Meteorol. Soc. 1999, 125, 1669-1679. [CrossRef] 